\title{
Semen Quality Characteristics and Effect of Mating Ratio on Reproductive Performance of Hubbard Broiler Breeders
}

\author{
Orunmuyi, Modupe ${ }^{1}$, Akanwa, Chidiebere Livinus ${ }^{1}, \&$ Nwagu Bartholomew Ifeanyi ${ }^{2}$ \\ ${ }^{1}$ Animal Science Department, Ahmadu Bello University, Zaria, Nigeria \\ ${ }^{2}$ National Animal Production Research Institute (NAPRI), Ahmadu Bello University, Shika, Zaria, Nigeria \\ Correspondence: Orunmuyi, Modupe, Animal Science Department, Ahmadu Bello University, Zaria, Nigeria. Tel: \\ 234-806-530-8475. E-mail: modupeorunmuyi@yahoo.com
}

Received: June 27, 2012 Accepted: July 27, 2012 Online Published: November 13, 2012

doi:10.5539/jas.v5n1p154

URL: http://dx.doi.org/10.5539/jas.v5n1p154

\begin{abstract}
A study was conducted at the National Animal Production Research Institute (NAPRI) Shika, Zaria, Nigeria to access some semen quality characteristics and to determine the effect of mating ratio on fertility and hatchability of Hubbard broiler breeders. 20 cocks were examined for semen quality characteristics. Parameters evaluated were: ejaculate volume, semen $\mathrm{pH}$, sperm concentration and sperm motility. Sequel to semen quality evaluation, hens were divided into three groups according to mating ratio (cock to hen) which included ratios 1:6, 1:7 and 1:8 with each group replicated 3 times. Each replicate was housed separately in pens. Hatchable eggs were collected after ten days grace period of mating and were set in the incubator. There were six hatches and fertility and hatchability parameters were calculated. Results obtained for semen quality characteristics showed that mean values for volume $(\mathrm{ml})$ was $0.55 \pm 0.04$, motility (\%) was 83.50 , concentration was $3.91 \times 10^{9} / \mathrm{ml}$, pH was 7.40 and average body weight was $4.73 \mathrm{~kg}$. Correlations between the semen quality characteristics and body weight showed that $\mathrm{pH}$ was negatively but not significantly correlated with volume, concentration and body weight. The correlation between volume and concentration was high $(0.92)$ and highly significant $(\mathrm{p}<0.001)$. Other correlations though positive were not significant $(p>0.05)$. Mating ratio significantly $(p<0.05)$ affected number of eggs fertile, number hatched and percent fertile. Birds mated in the ratio of 1:6 had the highest values for number fertile, number hatch and percent fertile but not significantly different from ratio 1:8. However the birds in the ratio of 1:7 had similar performance with those in the ratio $1: 8$ for percent fertile. High and significant correlation between ejaculate volume and concentration indicated that large ejaculate volume resulted in high concentration. Mating ratio of 1:6 was recommended to enhance fertility and hatchability especially in pedigree hatching.
\end{abstract}

Keywords: semen quality, mating ratio, hubbard broiler breeders

\section{Introduction}

The production of hatching eggs is the primary goal of a broiler breeder industry. Semen quality is therefore important to the industry due to its effect on the fertility and eventual hatchability of the eggs. In domestic fowl, a number of factors have been identified to affect fertility. Strain effects on oviductal sperm storage was reported by Brillard (1992). Sperm concentration of $50 \times 10^{6}$ was reported to be adequate for good fertility in chickens and turkeys (Bratte \& Ibe, 1989). The factors affecting hatchability include egg fertility and embryonic mortality (Fairchild et al., 2002). Failure of fertile eggs to hatch (embryonic mortality) could be as a result of prolonged egg storage, abnormal egg storage conditions, age of breeders and incubation problems (Fasenko et al., 1992; Wilson, 1997; Fairchild et al., 2002). The genetic effects of breeds, varieties and individuals within breeds on fertility and hatchability have been identified (Islam et al., 2002).

Studies to compare mating ratios are important for optimizing the breeding efficiency of broiler breeder flocks. Burke and Mauldin (1985) suggested that behavioral factors may be playing an important role in determining male reproductive success. Increased aggression and reduced frequency of courtship are behavioral characteristics affecting male broiler breeder reproductive ability (Millman \& Duncan, 2000; Millman et al., 2000). Reports of Casanovas and Wilson (1999) showed that a mating ratio of 1:10 in broilers gave the best fertility because it combined a good level of mating activity with relatively low interference and aggression. 
Bilcik et al. (2005) observed a high male fertility when housed individually with 4 hens. Reports on mating ratios for pedigree hatching in broiler selection experiment under natural mating are not available in Nigeria.

The objectives of this study were:

(i) To access some semen quality characteristics of Hubbard broiler breeder cocks.

(ii) To determine the effect of mating ratio on fertility and hatchability of Hubbard broiler eggs.

\section{Materials and Methods}

This study was carried out at the poultry breeding unit of the National Animal Production Research Institute (NAPRI) Shika, Zaria, Nigeria. The poultry lies between $11^{\circ} 12^{\prime} 42^{\prime \prime} \mathrm{N}$ and $7^{\circ} 33^{\prime} 14^{\prime \prime} \mathrm{E}$ at an altitude of $691 \mathrm{~m}$ above sea level (Ovimaps, 2011).

A total of 63 broiler breeder hens and 20 cocks were used for this study. All the hens and cocks used for this experiment were housed in a deep litter floor pen using wood shavings about $3 \mathrm{~cm}$ layer deep covering on the floor. Feeders and drinkers were provided for each pen. Birds were vaccinated against Newcastle disease using intraocular (I/O) Newcastle disease vaccine and Marek's vaccine against Marek's disease at day old. At 14 and 28 days, birds were vaccinated against Gomboro while Lasota was administered at 21 days. At 8 weeks, fowl pox and kumorov were administered to the birds and at 16 weeks, a booster dose of Kumorov was also administered to the birds. Routine medications were also carried out. Birds were fed with chick starter ration from 0-4 weeks containing 18-20\% Crude Protein, growers from 4-20 weeks containing 15-16\% Crude Protein. From 21 weeks of age, females were fed pre-breeder ration with 16-17\% Crude Protein and at 24 weeks or $1 \%$ production a Crude Protein of $15-16 \%$ was fed. The Metabolizable Energy of the feeds ranged from 2750-2800 $\mathrm{kcal} / \mathrm{kg}$. Feeding programme was according to the breeders' guide. Water was offered $a d l i b$.

\subsection{Experimental Procedure}

20 cocks were examined for semen quality characteristics between 38-41 weeks of age. Semen was collected from cocks thrice once in a week. Parameters evaluated were, ejaculate volume, semen $\mathrm{pH}$, sperm concentration and sperm motility. The hens were divided into three groups according to mating ratio (cock to hen). These included ratios 1:6, 1:7 and 1:8 with each group replicated 3 times. Each replicate was housed separately in pens. The cocks were then allowed to mate freely with the hens. Mating commenced from 42 weeks through 47 weeks of age. A ten day grace period was allowed before fertile eggs were collected for hatching. Fertile eggs were marked according to Sire number/pen number since there was only one cock in a pen. Eggs were weighed to the nearest $1 \mathrm{~g}$ and were stored for a maximum of 7 days at a temperature of $16^{\circ} \mathrm{C}$. There were six hatches.

\subsection{Candling and Hatching}

After setting in trays, eggs were weighed then fumigated, before being set in the incubator during which period eggs were turned on a regular basis. On the $18^{\text {th }}$ day of incubation, eggs were candled using a bright electric bulb/fluorescent tube; the number of infertile eggs were recorded for each group and then removed from the set eggs. The number of fertile eggs were recorded after which the fertile eggs were transferred to the Hatcher for 3 days (until hatch). Data on fertility and hatchability were recorded for each hatch. Percent fertility, percent hatch and percent hatchability were calculated as follows.

$$
\begin{array}{r}
\text { Percent Fertile }=\frac{\text { Total number of fertile eggs }}{\text { Total number of eggs set }} \times 100 \\
\text { Percent Hatch }=\frac{\text { Total number of chicks hatched }}{\text { Total number of eggs set }} \times 100 \\
\text { Percent Hatchability }=\frac{\text { Total number of chicks hatched }}{\text { Total number of fertile eggs }} \times 100
\end{array}
$$

On the day of hatching, all chicks were wing-banded and pedigreed by sire. The chicks were vaccinated against Newcastle disease using intraocular (I/O) Newcastle disease vaccine and Marek's vaccine against Marek's disease. Chick weights were also recorded. Data collected for the six hatches included

(i) Number of fertile eggs, number of hatched chicks and hatching weight.

(ii) Number of chicks hatched per mating ratio.

All the data collected on semen quality and mating ratio were analyzed using the GLM procedure of SAS (2002). Differences between the means for mating ratio were seperated using Duncan's Multiple Range Test. 


\section{Results and Discussions}

\subsection{Means of Semen Quality Characteristics}

Table 1 showed the Mean, Standard Error (SE) and Coefficient of variation (CV) of the semen quality characteristics and body weight. The values obtained were $0.55 \mathrm{mls}, 83.50 \%, 3.91 \times 10^{9} \mathrm{mls}, 7.40$ and $4.73 \mathrm{~kg}$ for volume, motility, concentration, $\mathrm{pH}$ and body weight respectively. The coefficient of variation ranged from 8.46 to $43.64 \%$. It was highest for semen volume and lowest for body weight.

Table 1. Means and coefficient of variation of semen quality characteristics

\begin{tabular}{lcc}
\cline { 2 - 3 } Parameters & Means \pm SE & CV (\%) \\
\cline { 2 - 3 } Volume $(\mathrm{ml})$ & $0.55 \pm 0.04$ & 43.64 \\
Motility( \%) & $83.50 \pm 2.64$ & 17.31 \\
Concentration & $3.91 \pm 11.69$ & 40.93 \\
$\left(\mathrm{x} 10^{9} / \mathrm{ml}\right)$ & $7.40 \pm 0.21$ & 15.27 \\
$\mathrm{pH}$ & $4.73 \pm 0.07$ & 8.46 \\
\hline
\end{tabular}

$\mathrm{CV}=$ Coefficient of Variation.

The mean for semen volume $(0.55 \mathrm{ml})$ obtained in this study was found to be in the range of $0.34-0.59 \mathrm{ml}$ reported by Bilcik et al. (2005) on broiler cocks and 0.40-0.73 ml obtained by Peters et al. (2008) on seven different indigenous chickens. The value for motility also fell within the range obtained by Peters et al. (2008), who reported a range of $70 \%$ to $87.35 \%$ as well as within the range of $74.5-85.67$ reported by Tabatabaei et al. (2010) on Iranian broiler breeder chickens but was higher than the $73.9 \%$ reported by Bah et al. (2001). Concentration was within the range of 3.40-9.70 billion/cc reported by Bilcik et al. (2005) but lower than the 4.3 billion sperm $/ \mathrm{ml}$ obtained by Moya et al. (1996) in broiler cocks and 6.6 billion sperm $/ \mathrm{ml}$ reported by Tabartabaei et al. (2009) on Ross broiler breeder. It was however higher than values of 2.17-3.14 x109 reported by Tabartabaei et al. (2010) and the $2.26 \times 10^{9}$ reported by Bah et al. (2001) on Nigerian local breeder cocks . The mean $\mathrm{pH}$ obtained in this study was within the range obtained by Peters et al. (2008), Gebriel et al. (2009) and Abd El Ghany et al. (2011).

Differences in values of semen quality characteristics of the roosters used in this study and some of those reported in literatures can been attributed to effects of strain, body weight, age and season. Strain differences in volume, concentration and motility but not $\mathrm{pH}$ had been reported by Abd El Ghany et al. (2011) while Udeh et al. (2011) reported significant difference in volume but not in concentration and motility due to strain effect. Makhafola et al. (2012) reported strain differences in ejaculate volume, semen $\mathrm{pH}$, sperm concentration and total motility while Tabartabaei et al. (2009) reported significantly higher motility in indigenous roosters than from the Ross breed of male.

Body weight was reported by Gebriel et al. (2009) to have significant effect on concentation and motility but not on semen volume and $\mathrm{pH}$ in Norfa chickens while Abd El Ghany et al. (2011) reported body weight influence on volume, concentration and motility but not $\mathrm{pH}$ in two local strains of chickens. These authors reported that the heavy weight had the advantage of high concentration but motility was to the advantage of the light weight group.

Age difference had been reported to affect concentration and motility but not volume and $\mathrm{pH}$ while season (hot or cold) affected volume, concentration, motility and pH. (Gebriel et al., 2009).

\subsection{Relationships between Semen Quality Characteristics and Body Weight}

Table 2 showed the correlations between the various semen quality traits and body weight. All correlations were positive except the correlation between $\mathrm{pH}$ and volume, $\mathrm{pH}$ and concentration, and $\mathrm{pH}$ and body weight. Most correlations irrespective of direction ranged from low to moderate and not significant. However only the correlation between volume and concentration was significant $(\mathrm{p}<0.001)$ and very high $(0.92)$. 
Table 2. Correlation between various semen quality traits

\begin{tabular}{lccccc}
\hline & $\begin{array}{c}\text { Volume } \\
(\mathrm{ml})\end{array}$ & $\begin{array}{c}\text { Motility } \\
(\%)\end{array}$ & $\begin{array}{c}\text { Concentration } \\
\left(\mathrm{x} 10^{9} \mathrm{ml}\right)\end{array}$ & $\mathrm{pH}$ & Body Weight $(\mathrm{kg})$ \\
\hline Volume ml & & $0.14^{\mathrm{NS}}$ & $0.92^{* * *}$ & $-0.33^{\mathrm{NS}}$ & $0.18^{\mathrm{NS}}$ \\
Motility $(\%)$ & & $0.22^{\mathrm{NS}}$ & $0.02^{\mathrm{NS}}$ & $0.12^{\mathrm{NS}}$ \\
Concentration $\left(\mathrm{x} 10^{9} \mathrm{ml}\right)$ & & & & $-0.16^{\mathrm{NS}}$ & $0.28^{\mathrm{NS}}$ \\
$\mathrm{pH}$ & & & & $-0.02^{\mathrm{NS}}$ \\
Body Weight $(\mathrm{kg})$ & & & & \\
$* * *=(\mathrm{P}<0.001)$. & & & &
\end{tabular}

The high positive and significant correlation between volume and concentration had been reported. (Bilcik et al., 2005; Gebriel et al., 2009; Abd El Ghany et al., 2011). These authors also reported negative correlation between volume and $\mathrm{pH}$, body weight and $\mathrm{pH}$ but positive correlation between concentration and $\mathrm{pH}$ which agreed with the results of this study. It was also observed from this study that body weight was positively but not significantly correlated with volume and concentration. Some other reports have shown positive relationship between these parameters (Gebriel et al., 2009; Abd El Ghany et al., 2011). Positive correlation between body weight and volume had also been reported by El Sahn (2007). However Makhafola et al. (2012) reported that body weight was negatively correlated with ejaculate volume, semen concentration and $\mathrm{pH}$ in Naked neck and Ovampo but positive correlation was reported between body weight and volume in Potchfstroom Koekoek strains of Southern African indigenous cockerels.

\subsection{Effect of Mating Ratio on Reproductive Performance}

Table 3 showed the effect of mating ratio on reproductive parameters. Number of fertile eggs, number of eggs hatched and percent fertile showed significant differences. Percent hatch and percent hatchability were not significantly different. Birds mated in the ratio of 1:6 had the highest values for number fertile, number hatch and percent fertile but not significantly different from ratio 1:8. However the birds in the ratio of $1: 7$ had similar performance with those in the ratio 1:8 for percent fertile. The inconsistencies in the results obtained due to mating ratio may be due to males behaving differently towards different females (Millman \& Duncan, 2000). It has been reported that males show mate preferences and will court some individual females more than others within a flock (Blohowiak et al., 1980). Male aggression towards females in commercial broiler breeder industry has been reported to make females less accessible to males due to previous injury (Mench, 1993). Generally, male fertility is based upon ability to perform a successful copulation and the quality of semen produced.

Table 3. Effect of mating ratio on reproductive parameters

\begin{tabular}{lllll}
\hline Parameters & \multicolumn{4}{c}{ Mating Ratios } \\
\hline Number set & $1: 6$ & $1: 7$ & $1: 8$ & LOS \\
Number Fertile & $12.89 \pm 1.18$ & $11.11 \pm 1.18$ & $13.53 \pm 1.2$ & NS \\
Number Hatch & $10.61^{\mathrm{a}} \pm 0.9$ & $6.22^{\mathrm{b}} \pm 0.9$ & $9.41^{\mathrm{a}} \pm 0.93$ & $*$ \\
Percent Fertile & $6.72^{\mathrm{a}} \pm 0.65$ & $4.00^{\mathrm{b}} \pm 0.65$ & $6.24^{\mathrm{a}} \pm 0.67$ & $*$ \\
Percent Hatch & $82.52^{\mathrm{a}} \pm 4.9$ & $60.21^{\mathrm{b}} \pm 4.9$ & $73.47^{\mathrm{a}} \pm 5.0$ & $*$ \\
Percent Hatchability & $53.54 \pm 4.73$ & $39.64 \pm 4.73$ & $49.05 \pm 4.88$ & NS \\
\hline
\end{tabular}

Means within the same row with different superscripts are significantly different;

$*=\mathrm{P}<0.05$, NS- Not Significant.

The differences observed in the number of fertile eggs and percent fertile obtained due to mating ratios 1:6, 1:7 and 1:8 may be attributed to differences in the reproductive ability of the cocks. Each cock differs in its ability to produce semen. This agrees with reports made by McGary et al. (2003). Another factor to consider is the differences in the semen storage tubule capacity that might exist between the hens. Other factors that could 
influence the number of sperm at the site of fertilization include egg location within the oviduct and sperm characteristics such as mobility (Fronman et al., 1997; Donoghue et al., 1998) and viability (Baskt et al., 1994).

\section{Conclusion}

It was concluded that the semen quality of the cocks fell within reported values for other chicken breeds. High and significant correlation between ejaculate volume and concentration indicated that large ejaculate volume resulted in high concentration. Mating ratio of 1:6 was recommended to enhance fertility and hatchability especially in pedigree hatching.

\section{Acknowledgement}

The authors are grateful to the management of National Animal Production Research Institute (NAPRI), Shika, Zaria, Nigeria for providing the facilities for this study.

\section{References}

Abd El Ghany, F. A., Alm El Dein, A. K., Soliman, M. M., Rezza, A. M., \& El-Sodany, S. M. (2011). Relationship between some body measurements and fertility in males of two local strains of chickens. Egyptian Poultry Science, 32(II), 331-349.

Bah, G. S., Chaudhari, S. U. R., \& Al-Amin, J. D. (2001). Semen characteristics of local breeder cocks in the sahel region of Nigeria. Revue Elev. Med. Vet. Pays trop., 54(2), 153-158.

Bakst, M. R., Wishart, G. J., \& Brillard, J. P. (1994) Oviducal sperm selection, transport and storage in poultry. Poulry Science Review, 5(1994), 117-143.

Bilcik, B., Estevez, I., \& Russek-Cohen, E. (2005). Reproductive success of broiler breeders in natural mating systems: The effect of male-male competition, sperm quality and, morphological characteristics. Poultry Science, 84, 1453-1462.

Blohowiak, C. C., Siegel, B. B., \& Vankrey, H. P. (1980). Sexual behaviour of dwarf and normal genotypes in divergent growth lines of chickens. Applied Animal Ethology, 6,189-210.

Bratte, L., \& Ibe, S. N. (1989). Optimal insemination interval, semen dose and dilution for optimum fertility in chickens under humid tropical conditions. Animal Reproduction Science, 20, 179-185. http://dx.doi.org/10.1016/0378-4320(89)900833

Brillard, J. P. (1992). Factors affecting oviductal sperm storage in domestic fowl following artificial insemination. Animal Reproduction Science, 27, 247-256. http://dx.doi.org/10.1016/0378-4320(92)90062-1

Burke, W. H., \& Mauldin, J. M. (1985). Reproductive characteristics of broiler breeder males from flocks with low fertility. Poultry Science, 64(Suppl. 1), 73.

Casanovas, P., \& Wilson, J. L. (1999). Spiking influence on fertility and reproductive behavior of broiler breeder. Poultry Science, 78(Suppl. 1), 119.

Donoghue, A. M. (1999). Prospective approaches to avoid flock fertility: Predictive assessment of sperm function traits in poultry. Poultry Science, 78, 437-443.

El-Sahn, A. A. (2007). Use of phenotypic traits to predict cocks fertility, 2. The ornamental and non-ornamental traits. Egyptian Poultry Science, 27, 1085-1097.

Fairchild, B. D., Christensen, V., Grimes, L., Wineland, J., \& Bagley, L. (2002). Hen age relationship with embryonic mortality and fertility in commercial turkeys. Journal of Applied Poultry Research, 11, 260-265. Retrieved from http://japr.fass.org/cgi/reprint/11/3/

Fasenko, G. M., Hardin, R. T., \& Robinson, F. T. (1992). Relationship of hen age sequence position with fertility, hatchability, viability and preincubation embryonic development in broiler breeders. Poultry science, 71, 1374-1383.

Froman, D. P., Feltman, A. J., \& McLean, D. J. (1997). Increased fecundity resulting from semen donor selection based upon in vitro sperm mobility. Poultry science, 76, 73-77.

Gebriel, G. M., Kalamah, M., El-Fiky, A., \& Ali, A. F. A. (2009). Some factors affecting Semen quality trait in Norfa cocks. Egyptian Poultry Science, 29(11), 677-693.

Islam, M. S., Howlinder, M. A. R., Kabir, F., \& Alam, J. (2002). Comparative assessment of fertility and hatchability of Barred Plymouth Rock, White Leghorn, Rhode Island Red or White Rock hen. International Journal of Poultry Science, 1, 85-90. 
Makhafola, M. B., Umesiobi, D. O., Mphaphathi, M. L., Masenya, M. B., \& Nedambale, T. L. (2012). Characterization of sperm cell motility rate of Southern African indigenous cockerel semen following Analysis by sperm class analyzer. Journal Animal Science Advances, 2(4), 416-424.

McGary, S., Estevez, I., \& Baskt, M. R. (2003). Potential relationships between physical traits and male broiler breeder fertility. Poultry Science, 82, 328-337.

Mench, J. A. (1993). Problems associated with broiler breeder management. In C. J. Savory \& B. O. Hughes (Eds.), Proceedings of the Fourth European Symposium on Poultry Welfare (pp. 195-207). Universities Federation for Animal Welfare, Potters Bar, UK.

Millman, S. T., \& Duncan, I. J. H. (2000). Do female broiler breeder fowl display a preference for broiler breeder or laying strain males in a Y-maze test? Applied Animal Behaviour Science, 69, 275-290.

Millman, S. T., Duncan, I. J. H., \& Widowski, T. M. (2000). Male broiler breeder fowl display high levels of aggression toward females. Poultry Science, 79, 1233-1241.

Moya, A, Gonzalez, A., \& Capote, M. (1996). Selection of White Leghorn cocks for artificial insemination 1: sire semen evaluation. Poultry Science, 75, 1112-1119.

Ovimaps (2011). Ovi location map; Ovi earth imagery date; November 5th, 2011.

Peters, S. O., Shoyebo, O. D., llori, B. M., Ozoje, M. O., Ikeobi, C. O. N., \& Adebambo, O. A. (2008). Semen quality traits of seven strain of chickens raised in the humid tropics. International Journal of Poultry Science, 7(10), 949-953.

SAS. (2002). Statitiscal Analysis System Multiple Incorporation. Users Guide Statistical Version, Cary, N.C . USA.

Tabatabaei, S., Chaji, M., \& Mohammadabadi, T. (2010). Correlation between age of rooster and semen quality in Iranian indegenous broiler breeder chickens. Journal of Animal and Veterinary Advances, 9(1), 195-198.

Tabatabaei, S., Batavani, R. A., \& Talebi, A. R. (2009). Comparison of semen quality in indigenous and Ross broiler breeder roosters. Journal of Animal Veterinary Advances, 8, 90-93.

Udeh, I., Ugwu, S. O. C., \& Ogagifo, N. L. (2011). Predicting semen traits of local and exotic cocks using linear body measurements. Asian Journal of Animal Science, 5(4), 268-276.

Wilson, H. R. (1997). Effects of maternal nutrition on hatchability. Poultry Science, 76, 134-143. 